\title{
Serpentinite enigma of the Rakhabdev lineament in western India: Origin, deformation characterization and tectonic implications
}

\author{
Dyuti Prakash SARKAR ${ }^{*}$, Jun-ichi ANDO ${ }^{*}$, Kaushik DAs*, Anupam ChATTOPADHYAY ${ }^{* *}$,

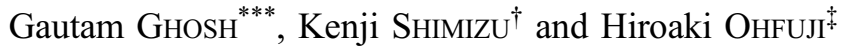 \\ *Department of Earth and Planetary Systems Science, Hiroshima University, Hiroshima 739-8526, Japan \\ ${ }^{* *}$ Department of Geology, University of Delhi, Delhi 110007, India \\ ${ }^{* * *}$ Centre for Advanced Study, Department of Geology, Presidency University, Kolkata 700073, India \\ ${ }^{\dagger}$ Kochi Institute for Core Sample Research, JAMSTEC, Kochi 783-8502, Japan \\ *Geodynamics Research Center, Ehime University, Ehime 790-8577, Japan
}

\begin{abstract}
Serpentine mineralogy controls fault rheology in the ocean and continental rift settings to subduction settings and hence can be used to discern the paleo deformational conditions. The Rakhabdev lineament from Rajasthan, India, provides a unique opportunity to understand its tectonic evolution inferred from the deformation microstructures. However, the complexity of surrounding calc-silicate rocks had resulted in a long-driven debate on the origins of these serpentinite rocks. The source rocks of the serpentinites also cannot be determined previously due to complete serpentinization and metasomatism rendering complete alteration of the source rocks. In this study, the serpentinite mineral was analyzed using Raman spectroscopy to accurately characterize its molecular structure. The presence of the antigorite-variety of serpentine mineral indicate towards the origin of Rakhabdev serpentinites in the upper mantle condition. The antigorite serpentinite of Rakhabdev is a hydration product of mantle materials showing high $\mathrm{Mg} \#$ values obtained from EPMA data. The microstructural and EBSD analysis also indicates two stages of deformation, with deformation of antigorite at upper mantle conditions, followed by their shallow crustal carbonate metasomatism and subsequent deformation of the carbonates, with later stage calcite vein intrusion. This resulted in the appearance of antigorite in contact with calcite, dolomite, talc, tremolite, and chlorite. The exhumation of mantle wedge antigorite serpentinite is, therefore, indicating a paleo-subduction zone culminating in a crustal-scale collision boundary expressed as arcuate discontinuous bodies forming the Rakhabdev lineament.
\end{abstract}

Keywords: Rakhabdev serpentinite, Antigorite deformation, Calcite CPO, Raman spectroscopy

\section{INTRODUCTION}

Serpentinites typically form due to the hydration of peridotite at temperatures ranging from $\sim 200$ to $\sim 600^{\circ} \mathrm{C}$, resulting in the alteration of $\mathrm{Mg}$-rich olivine and orthopyroxene to serpentine minerals (Evans et al., 2013). The common serpentine minerals chrysotile, lizardite, and antigorite have similar chemical composition, yet very different crystal structure (Wunder et al., 2001; Rinaudo et al., 2003). Chrysotile has a coiled structure responsible for its asbestiform properties, while lizardite has a planar structure, and antigorite has a wave-like structure (Wicks and Whittaker, 1975; Uehara, 1998). Structural type of

doi:10.2465/jmps. 191016

D.P. Sarkar, sarkardp16@hiroshima-u.ac.jp Corresponding author J. Ando, jando@hiroshima-u.ac.jp serpentine mineral present provides insights into the depth of serpentinization (Wunder et al., 2001; Bromiley and Pawley, 2003), and the microstructures developed within them help in characterization of the deformation processes activated in the region of their occurrence. The antigorite, formed as a result of serpentinization of mantle peridotites, is stable in the upper mantle condition. Their formation occurs in an $\mathrm{MSH}\left(\mathrm{MgO}-\mathrm{SiO}_{2}-\mathrm{H}_{2} \mathrm{O}\right)$ or MASH $\left(\mathrm{MgO}-\mathrm{Al}_{2} \mathrm{O}_{3}-\mathrm{SiO}_{2}-\mathrm{H}_{2} \mathrm{O}\right)$ system (Wunder et al., 2001). The antigorite develops from water stored in mantle conditions in the high $P-T$ stability field of the serpentine, primarily by slab dehydration below mantle wedge overlying a subducting slab (Arai and Ishimaru, 2008; Debret et al., 2019; Uno and Kirby, 2019). The unique alternating wave structure characteristic of antigorite and its crystal preferred orientation (CPO) are con- 
trolled by the original olivine fabric of the mantle wedge (Boudier et al., 2009) and acts as a controlling factor in fluid flow pathways and seismic anisotropy of the subduction zones (Hirauchi et al., 2010; Kawano et al., 2011; Campione and Capitani, 2013; Mizukami et al., 2014).

The studies on antigorite deformation, however, are limited to recent subducting slab (Andreani et al., 2007; Hirauchi et al., 2010; Plissart et al., 2019), and studies on paleo-subduction zones have been rarely investigated especially the completely metasomatized paleo-subduction zones. Since, different serpentinite minerals can deform at variable depths, identifying the chemical and structural variety of the serpentine minerals help in their characterization as metasomatized mantle wedge materials. The study of such serpentinite bodies can help in the understanding of the conditions of the metasomatism, deformation mechanisms, and tectonic evolution of the subduction zone. Such paleo-subduction zones are major components of the orogenic belt that stich older cratonic blocks and occurs within present-day continental crust.

One such orogenic belt is the Aravalli-Delhi Mobile Belt (ADMB) in the state of Rajasthan, India, where few studies (Deb et al., 1989; Sarkar et al., 1989; Sugden et al., 1990; Verma and Greiling, 1995; Deb and Thrope, 2001; Singh et al., 2010; Purohit et al., 2015; Tiwari and Biswal, 2019) have reported the occurrence of serpentinites within Proterozoic meta-sediments. The fragmented bodies of serpentine rock occur along Rakhabdev lineament between the Jharol Group and the lower-middle Aravalli Group of rocks. However, due to a lack of studies in chemical characterization and complexity of the deformation and metamorphism in the area, the origin of these rocks is still an enigma. Two prevalent theories about their origin are the serpentinization of structurallycontrolled ultramafic intrusions and the serpentinization in the paleo-subduction zone (Sarkar et al., 1989; Verma and Greiling, 1995). Lack of evidence and dearth in studies have rendered both the theories debatable (Sugden et al., 1990; Abu-Hamatteh et al., 1994; Gathania et al., 1995; Shekhawat et al., 2010).

The present study aims at identifying the molecular structure of the serpentine mineral specimen present within the serpentinite bodies to give insights into its origin. The study of deformation microstructures is also attempted to determine deformation conditions and their relation to the Aravalli-Delhi orogeny (Prasad et al., 1998). Few studies have been undertaken based on microstructures and geochemistry of the antigorite (Bhu et al., 2006; Purohit et al., 2015). However, accurate characterization of serpentinite and usage of EBSD to determine deformation mechanisms have not yet been reported from this area. This could help in elucidating the origin of the serpentinites which is present as arcuate discontinuous bodies within the metamorphosed Aravalli Supergroup of the ADMB.

\section{GEOLOGICAL BACKGROUND AND SAMPLE LOCALITY}

Rakhabdev (or Risabhadev) serpentinites constitute a series of continuous to detached (at places) bodies, occurring with a linear N-S trend for a distance of about $90 \mathrm{~km}$ between Gogunda in the north and Antri in the south, that defines the Rakhabdev lineament (Fig. 1), within the Aravalli Supergroup (Bhu et al., 2006). The ADMB comprises two major supracrustal units, viz., the Aravalli Supergroup and the Delhi Supergroup, and deposited on an Archaean basement known as the Banded Gneissic Complex (BGC) (Gupta et al., 1995; Heron, 1953; Roy and Jakhar, 2002; Sharma, 2010). The Aravalli Supergroup has been subdivided into the Lower, Middle and Upper Aravalli Groups (Roy and Jakhar, 2002). The lowest part of the succession is dominated by stromatolitic phosphorites and U-bearing black shales along with metabasalts. The middle part mostly comprises greywacke, carbonaceous phyllite, and conglomerate, and the upper part is dominantly quartzite, conglomerate, and phyllite which grades into mica schists with thin quartzite bands in the western side. Roy and Jakhar (2002) has designated the dominantly phyllite-mica schist-quartzite units as Jharol Group - a deep water facies, in contrast to the shelf facies associations dominating the eastern part of the Upper Aravalli Group (Gupta et al., 1997). The boundary between Jharol Group and Upper Aravalli Group is roughly marked by the occurrence of the serpentinites of Rakhabdev lineament (Bhu et al., 2006; Purohit et al., 2015), with type locality around Risabhadev area. The present study focusses on serpentinite samples collected from Gogunda and Risabhadev area within the Rakhabdev lineament (Fig. 1). A total of six serpentinite samples were collected (Table 1 and Fig. S1; Fig. S1 is available online from https://doi.org/10.2465/jmps. 191016).

\section{ANALYTICAL METHODS}

The thinsections $(\sim 30 \mu \mathrm{m})$ were prepared along XZ section (perpendicular to foliation and parallel to lineation) and polished with $1 \mu \mathrm{m}$ diamond paste, for petrographic observations. For EBSD analysis, two chip samples (cut along XZ section) of $1 \mathrm{~cm}$ by $1 \mathrm{~cm}$ were polished using IS Polisher 1000 at Kochi Core Center JAMSTEC facility to minimize the surface damage during polishing, followed by osmium coating at Hiroshima University. 


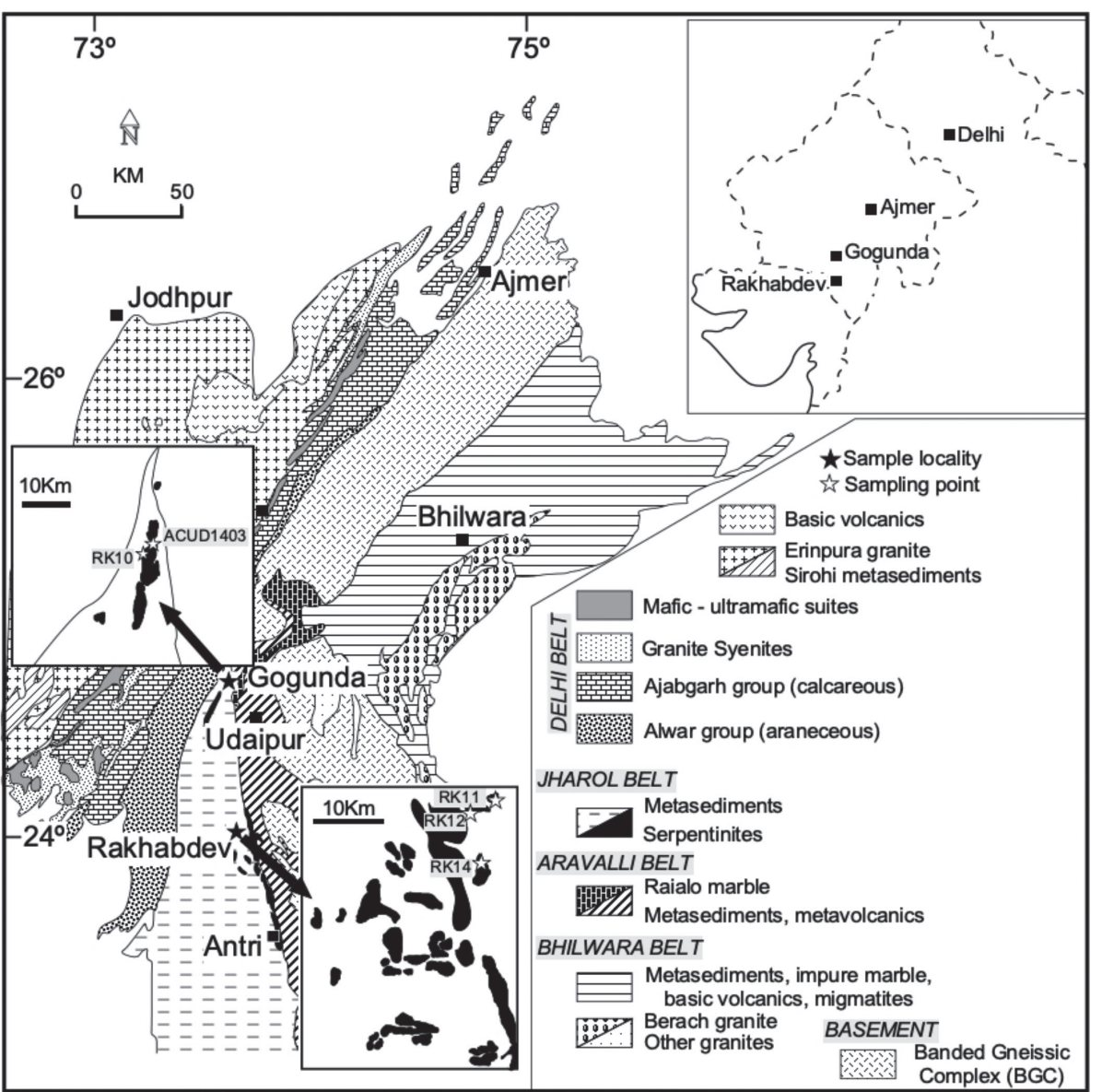

Figure 1. Geological map of the Aravalli-Delhi Mobile Belt, showing the occurrence of Rakhabdev serpentinites (Modified after Sugden et al., 1990). Inset shows the location of the study area. The sampling points are shown in the two enlarged areas of the sample locality marked by black arrows (modified after Purohit et al., 2015). Google images and GPS values of sampling locations (WGS84 projection system) are included in Figure S1 and Table 1 respectively. The preliminary structural data (foliation and lineation of serpentinites and crenulation orientation) is presented in Figure 3.
Table 1. Sample locations and photograph locations (GPS values WGS84 projection system)

\begin{tabular}{cccc}
\hline \multicolumn{4}{c}{ Sample locations } \\
Sample No. & Latitude (N) & Longitude(E) & Area \\
\hline ACUD1403 & 24.7931 & 73.5712 & \\
ACUD1404 & 24.7931 & 73.5712 & Gogunda \\
RK 10 & 24.7897 & 73.5657 & \\
RK 11 & 24.0784 & 73.7024 & \\
RK 12 & 24.0677 & 73.6913 & Rakhabdev \\
RK14 & 24.0463 & 73.6891 & \\
\hline \multicolumn{4}{c}{ Photograph location } \\
Figure No. & Latitude (N) & Longitude(E) & Area \\
\hline Figure 2a & 24.792627 & 73.571215 & Gogunda \\
Figure 2b & 24.078350 & 73.702373 & Rakhabdev \\
\hline
\end{tabular}

Principle of Raman spectroscopic analysis of serpentinite minerals

Raman spectra of serpentines in low wavenumber spectral range (150-1100 $\left.\mathrm{cm}^{-1}\right)$ corresponds to the inner vibrational modes of the lattice and to $\mathrm{Si}^{-} \mathrm{O}_{4}$ vibrations, while the high wavenumber spectra $\left(3550-3850 \mathrm{~cm}^{-1}\right)$ corresponds with the stretching vibrations of the $\mathrm{OH}$ groups of the water molecules (Petriglieri et al., 2015). Low wavenumber Raman spectra obtained shows strong peak of $230 \mathrm{~cm}^{-1}$, which is present in all serpentine polymorphs due to $\mathrm{O}-\mathrm{H}-\mathrm{O}$ vibrations, $\mathrm{O}$ being the non-bridging oxygen of $\mathrm{a} \mathrm{SiO}_{4}$ tetrahedron and $\mathrm{H}$ being the hydrogen of the outer $\mathrm{OH}$ group of the adjacent layer (Griffith and Wickins, 1967; Loh, 1973; Petriglieri et al., 2015). The peak at $680 \mathrm{~cm}^{-1}$, due to deformation vibrations of the $\mathrm{Si}-\mathrm{O}$ layer, the peak at $1044 \mathrm{~cm}^{-1}$, due to antisymmetric stretching mode $\left(\mathrm{v}_{\mathrm{as}}\right)$ of $\mathrm{S}-\mathrm{O}_{\mathrm{b}}-\mathrm{Si}$ groups, and the doublet at $3665 \mathrm{~cm}^{-1}$ and $3695 \mathrm{~cm}^{-1}$, implies the presence of antigorite variety of the serpentine mineral in the collected serpentinites (Auzende et al., 2004; Enami, 2006).

Raman Spectroscopic analyses of two thin sections representative of the serpentine minerals were conducted by JASCO NRS-5100 Raman Spectrometer at the Geodynamics Research Center (GRC) facility of Ehime University. The analysis was done using $532 \mathrm{~nm} \mathrm{Nd-YAG}$ laser and CCD detector. Collection times for Raman spectra were 6 or 12 accumulation of $10 \mathrm{~s}$ each. 

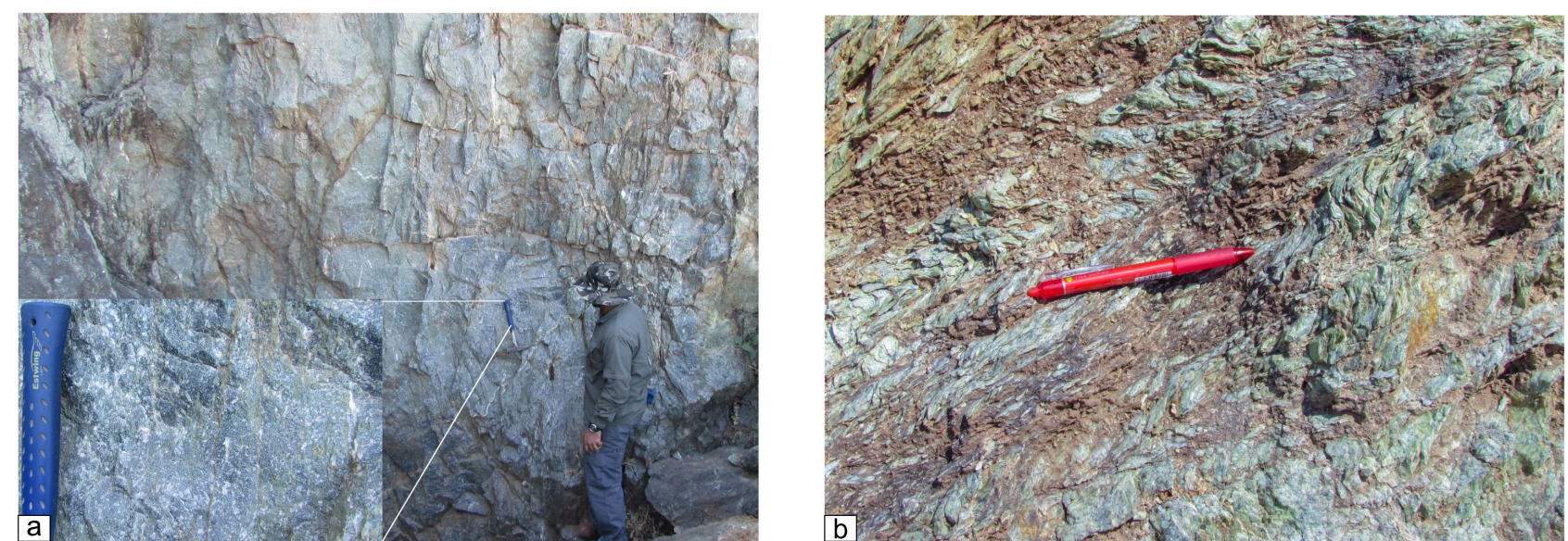

Figure 2. Outcrops from Jharol belt and Aravalli belt. (a) Calcite bearing talc-tremolite schist inset showing the development of sub-vertical foliation in the rock. (b) Deformed serpentinites occurring sporadically between talc-tremolite schists and pelitic schist. The crenulated nature visible in outcrop is a product of shallow crustal deformation overprinting the pre-existing foliation of the serpentinites.

\section{Electron Micro Probe Analysis}

The major element chemical compositions of the serpentines and the associated minerals including opaque minerals were done by EPMA (JEOL JXA-8200) at Natural Science Center for Basic Research and development (NBARD) facility of Hiroshima University with accelerating voltage of $15 \mathrm{kV}$ and $2 \mu \mathrm{m}$ beam size. ZAF method was applied for matrix corrections.

\section{Electron Backscatter Diffraction Analysis}

The crystallographic preferred orientation (CPO) was obtained point by point, for the calcite and antigorite by electron backscattered diffraction (EBSD) using the Nordlys system attached to scanning electron microscope JEOL JSM6390A, with accelerating voltage of $15 \mathrm{kV}$ and sample tilt of $70^{\circ}$. The obtained EBSD patterns were processed using the HKL Channel 5.0 software package.

\section{RESULTS}

The serpentinites occur in the field as detached bodies bounded by metapelites in the west and talc-tremolite schists (Fig. 2a) in the east. The actual contact of the metapelites and talc-tremolite schists with the serpentinites could not be identified in the studied area. The detached serpentinite bodies show a trend of NNE-SSW with subvertical foliation overprinted by crenulation cleavage trending NE-SW (Fig. 2b). The preliminary structural data of the foliation and lineation obtained from the serpentinite bodies and the measured crenulation cleavages are presented in Figure 3. The serpentinite samples, in thinsections show two types of assemblages. One as-

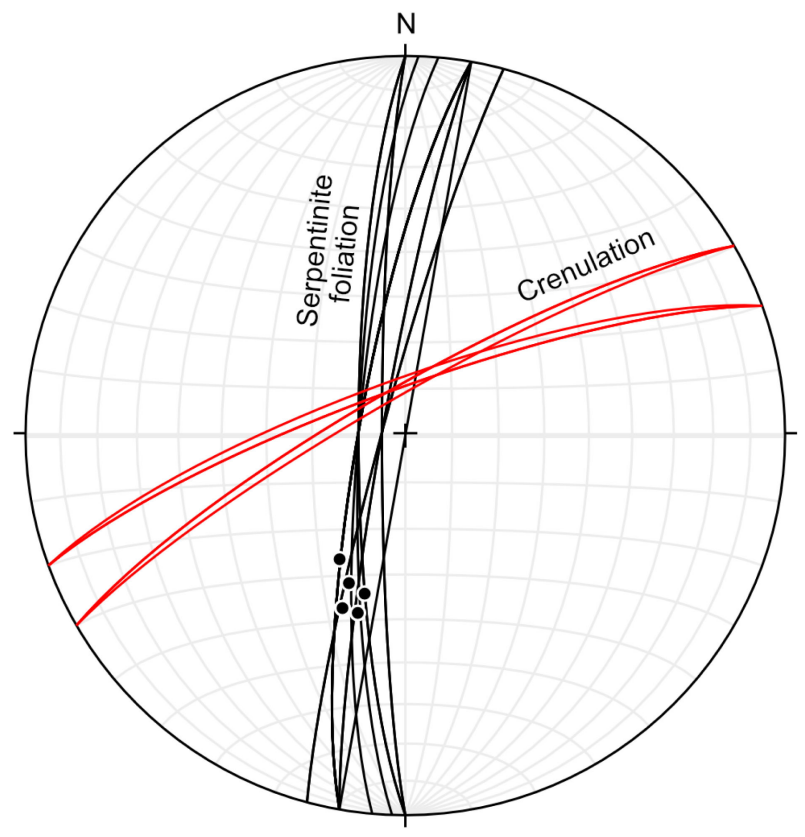

Figure 3. Stereonet plot of foliation and lineation of the serpentinites with the crenulation data. Crenulation cleavages $(n=6)$ are plotted as great circles in the stereonet. The serpentinite foliations $(n=17)$ represented by great circles and striping lineations (solid circles, $\mathrm{n}=8$ ) are plotted on them. The data is overlapped hence plotted data appears less than actual data.

semblage shows the presence of dominantly serpentine minerals (the type of serpentine mineral is identified using Raman spectroscopy) with opaque minerals (mineral composition determined by EPMA). The opaque minerals of this assemblage are primarily magnetite, with few relict $\mathrm{Cr}$-spinel. The other assemblage comprises of serpentine minerals with calcite, dolomite, talc, tremolite, and chlorite. The opaque minerals of the second assem- 

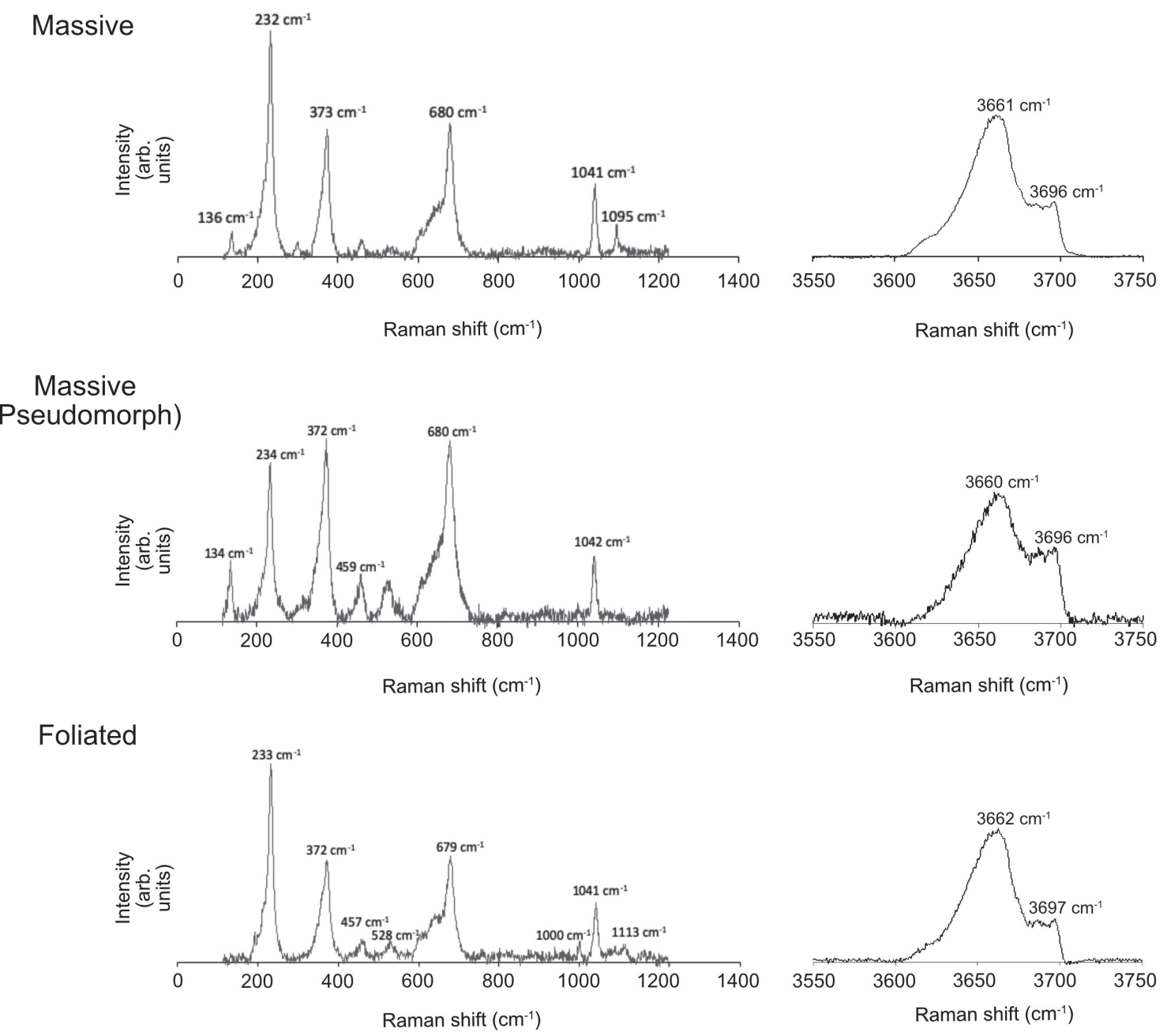

Figure 4. Raman spectra with $\boldsymbol{x}$-axis as Raman shift $\left(\mathrm{cm}^{-1}\right)$ and $\boldsymbol{y}$-axis as Raman intensity measured from representative serpentinites, the peaks at high wave number implies the antigorite variety of the serpentine minerals.

blage include dominantly magnetite and also include minor alteration to ulvöspinel. $\mathrm{Cr}$-spinel is not present in the serpentinite samples with calcite veins. Also, in the currently studied samples, no olivine grains could be identified. The serpentines exhibit massive (with interpenetrating blades) to foliated textures, with clasts of dolomite interspersed with massive serpentine minerals (discussed in later sections).

\section{Raman spectral analysis of serpentine}

The serpentinites primarily exhibit massive and randomly oriented blades or foliated nature observable in thinsections. Raman spectra of serpentines in low wavenumber spectral range $\left(150-1100 \mathrm{~cm}^{-1}\right)$ shows strong peak at $\sim 230, \sim 373, \sim 680$, and $\sim 1041 \mathrm{~cm}^{-1}$ (Fig. 4). The high wavenumber spectra $\left(3550-3850 \mathrm{~cm}^{-1}\right)$ shows the doublet at $\sim 3665$ and $\sim 3695 \mathrm{~cm}^{-1}$ (Fig. 4).

\section{Microstructural characterization and CPO}

The serpentinites contain dominantly antigorite and occur as massive or foliated. The massive antigorite shows the interpenetrative texture of the blades of antigorite (Fig. 5a). The $\mathrm{Cr}$-spinel grains preserved in the massive antigorite are fractured and show gradational zoning (Fig. 5b) of progressive $\mathrm{Fe}-\mathrm{enrichment}$ from the unaltered core towards the Fe-rich rim. They are present with the assemblage of interpenetrative antigorite without any secondary alteration minerals like chlorite. The massive antigorite is deformed into foliated antigorite (Fig. 5c), showing a slight variation in BSE contrast, corresponding to their variation in mineral content (composition). Few relict grains preserve the interpenetrative texture of the original antigorite and shape of original parent grains (Fig. 5d). The magnetite present in the foliated antigorite samples (Fig. 5e) does not exhibit any zoning. Prominent calcite veins (Fig. 5f) crosscut the foliation of the antigorite and 

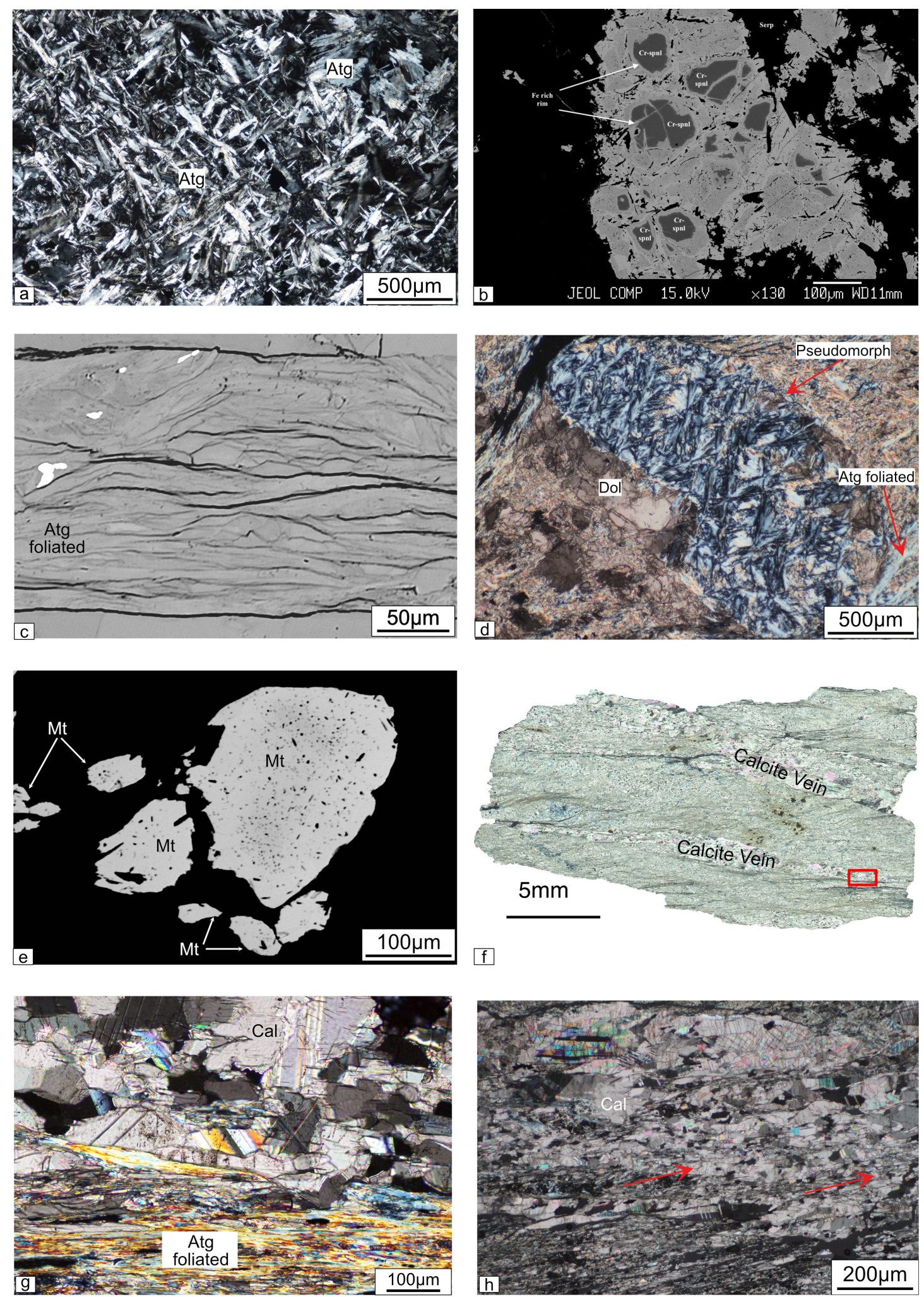

Figure 5. (a) XPL image of original antigorite shows interpenetrating structures. (b) SEM-BSE image of representative Cr-Spinel within the original antigorite shows Fe-enrichment from core to outer rim. (c) SEM BSE images of foliated antigorite. (d) Pseudomorphic grains preserving interpenetrative texture and showing alteration to foliated antigorite. (e) SEM-BSE image of magnetite grains in the foliated antigorite sample. (f) Thin section of foliated antigorite with later stage calcite veins cutting them at an angle. (g) Calcite vein crosscutting the foliated antigorite with assemblage of talc-tremolite-chlorite. (h) The XPL image of calcite veins [marked by rectangle in (f)], with recrystallized grains (arrows) and larger grains showing twin development and undulose extinction. 
are deformed by twinning and recrystallization (Figs. $5 \mathrm{~g}$ and $5 \mathrm{~h})$.

The EBSD analysis of the foliated antigorite (Fig. 6) obtained from XZ sections of the samples, exhibit well developed CPO (Fig. 7a), with multiples of uniform dis-

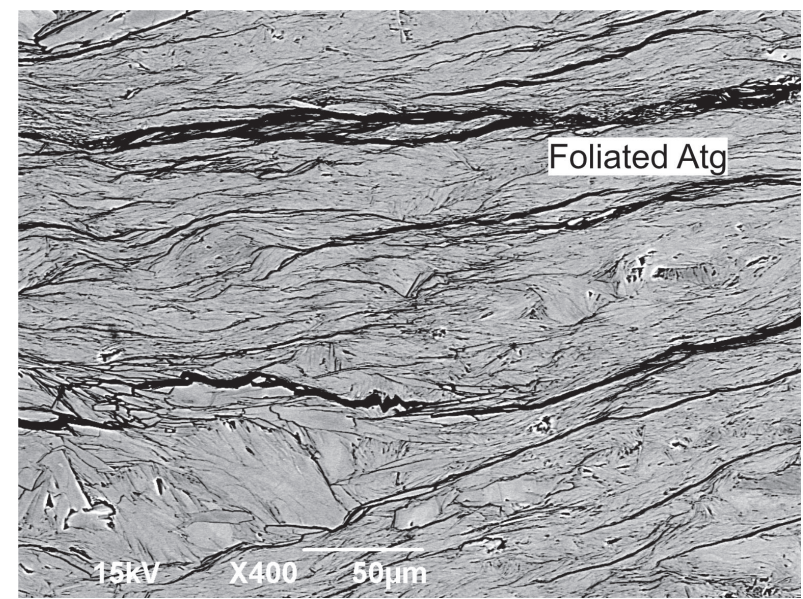

Figure 6. Representative area showing foliated antigorite grains for EBSD analysis. tribution (m.u.d) values 0.03-5.46. The [010] axes of antigorite are concentrated parallel to the lineation and [100] axes subnormal to lineation. This CPO pattern suggests the activation of [010] (001) slip system in antigorite. The calcite within the veins crosscutting the foliated antigorite has also developed a weak but distinctive CPO (m.u.d. 0.19-2.15), with [0001] axes parallel to vein direction and $\langle 11-20\rangle$ axes spread normal to the vein (Fig. $7 b)$. This CPO pattern is due to the dislocation creep with (0001) as the dominant slip plane for calcites deformed at mid- to high temperatures (de Bresser and Spiers, 1993; Austin et al., 2008; Vauchez et al., 2015).

\section{Mineral Chemistry}

The detailed compositions of the antigorite (inferred by the textural similarity with the representative antigorite grains determined by Raman spectroscopy) are listed in Supplementary Table S1 (available online from https:// doi.org/10.2465/jmps.191016).

The major total oxide of the antigorite ranges 84.58 $88.25 \%$. Recalculations of atomic proportions were done a
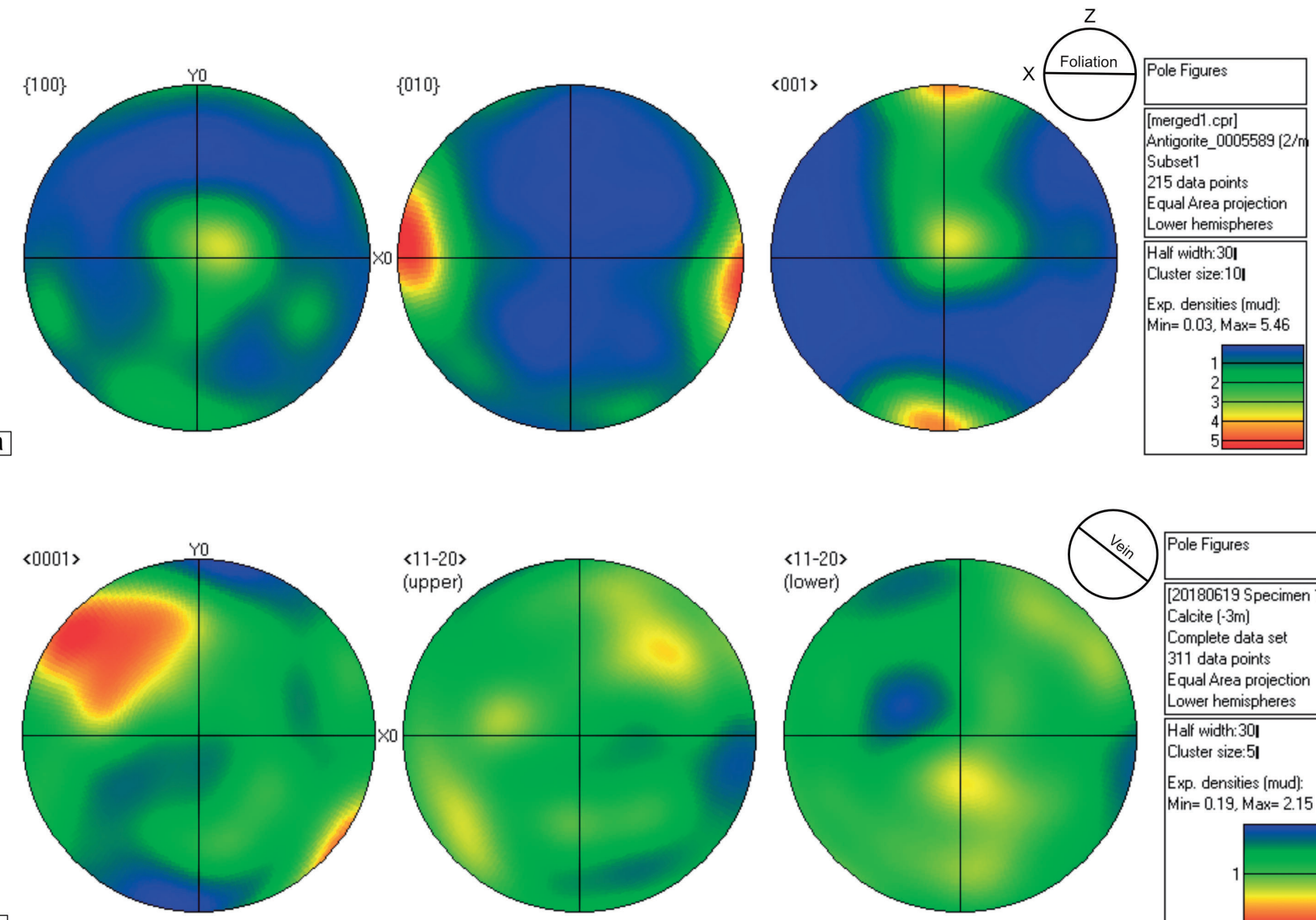

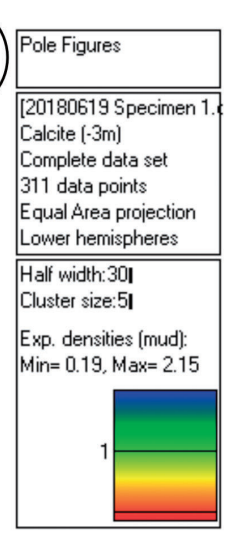

Figure 7. (a) Lower hemisphere pole figures of $\mathrm{CPO}$ of antigorite, shows development of [010] (001) slip system in the antigorite. (b) Lower hemisphere pole figures of CPO of deformed calcite veins, showing activation of $[0001]<11-20>$ slip system. 

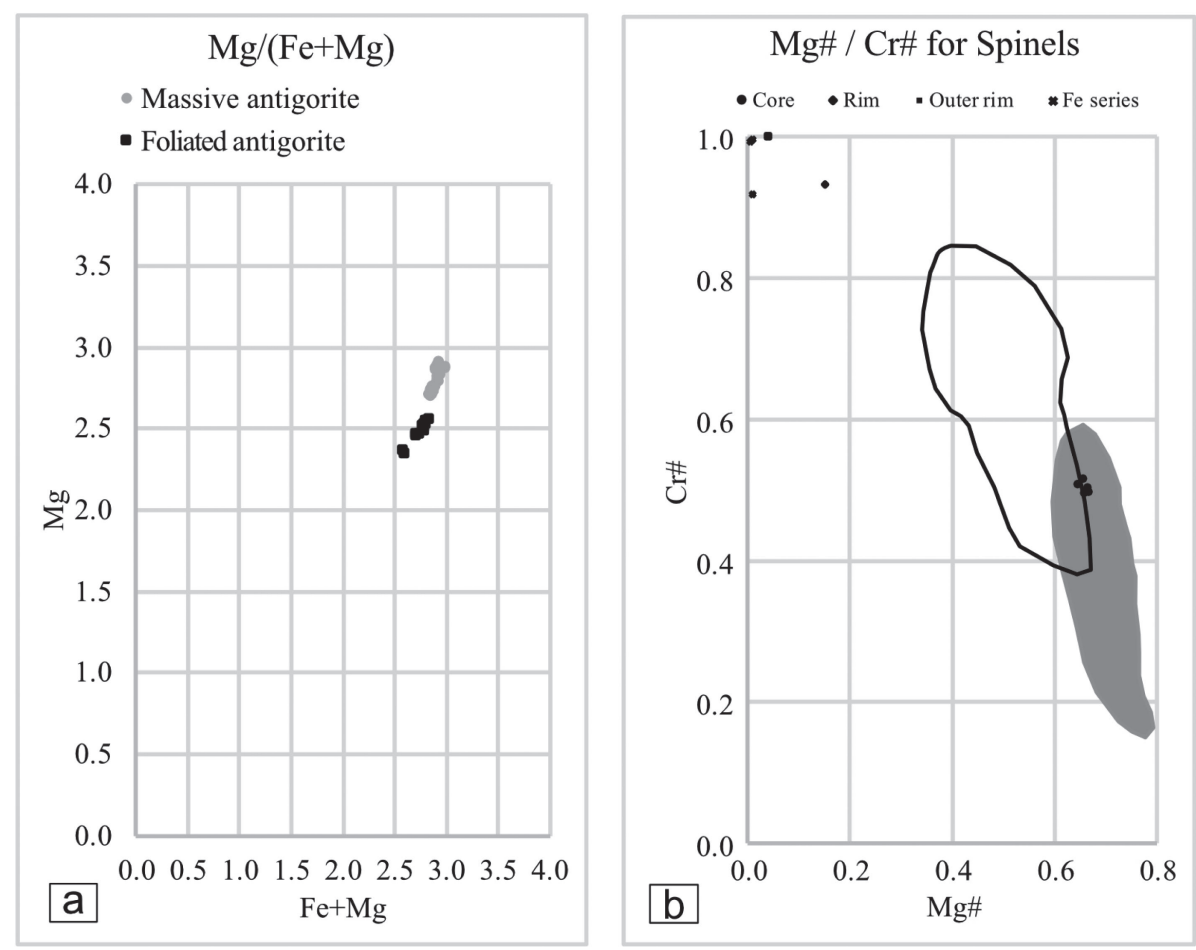

Figure 8. (a) $\mathrm{Mg}$ versus $(\mathrm{Fe}+\mathrm{Mg})$ plot for the antigorite samples, showing two distinct clusters with higher Mg\#(95-98) for original antigorite and a Mg\#(88.1-91) for antigorite in contact with calcite/dolomite veins. (b) $\mathrm{Mg} \#[\mathrm{Mg} /(\mathrm{Mg}+\mathrm{Fe})]$ versus $\mathrm{Cr} \#[\mathrm{Cr} /(\mathrm{Cr}+\mathrm{Al})]$ for the chromian spinels shows compositional affinity of the spinel in the common region of forearc and abyssal peridotites (Gamal El Dien et al., 2019). based on the seven oxygen and yields $\mathrm{Mg}$ number (88.80-91.13) for samples containing calcite and dolomite. The antigorite from zones without calcite and dolomite assemblage shows a higher $\mathrm{Mg}$ number (93.7898.70). No zoning within the individual antigorite grains was observed in SEM BSE, however, there is a variation in the Fe content of all the antigorite samples. The $\mathrm{Mg}$ versus $(\mathrm{Fe}+\mathrm{Mg})$ plot (Fig. 8a) shows clustering in two distinct zones, representing alteration in the antigorite chemistry in response to the presence of carbonate phases. The representative composition of the talc, chlorite, and spinel are also listed in Table S1. The mineralogical variation in $\mathrm{Cr}$-spinels is inferred by plotting its $\mathrm{Mg}$ number against its $\mathrm{Cr}$ number (Fig. $8 \mathrm{~b}$ ) and shows the compositional affinity of the spinel in the common region of forearc and abyssal peridotites (Arai and Ishimaru, 2008; Gamal El Dien et al., 2019).

\section{DISCUSSIONS}

\section{Generation and deformation of antigorite}

The absence of mantle minerals like olivine and pyroxenes within the observed samples renders the determination of source-rock mineralogy difficult. However, the predominance of only antigorite within the serpentinite (inferred from Raman spectroscopic analysis), and the mineralogy of the Cr-spinels (Fig. 8b) suggest the possibility of forearc peridotites as the source rock (Gamal El
Dien et al., 2019).

The interpenetrating microstructures of the original antigorite (Fig. 5a) that is also preserved in pseudomorph (Fig. 5d) shows deformation into oriented blades of antigorite forming the foliated antigorite (Figs. 5c and 5d). Since, all other phases are post to this massive antigorite and the foliated antigorite, therefore the serpentinization is a product of olivine + orthopyroxene system at pressure $>1.5 \mathrm{GPa}$ (Nakatani and Nakamura, 2016). The hydration of olivine and orthopyroxene resulting in the formation of antigorite is given by the following reaction (Pawley, 1998; Murata et al., 2009; Watanabe et al., 2011; Auzende et al., 2015).

$$
\begin{aligned}
& \mathrm{Mg}_{2} \mathrm{SiO}_{4}+\mathrm{MgSiO}_{3}+2 \mathrm{H}_{2} \mathrm{O} \rightarrow \mathrm{Mg}_{3} \mathrm{Si}_{2} \mathrm{O}_{5}(\mathrm{OH})_{4} \\
& \text { Olivine + Orthopyroxene + water } \rightarrow \text { Antigorite }
\end{aligned}
$$

The presence of the Cr-Spinel as opaque mineral (without any hydrous phases like chlorite) and the $\mathrm{Mg}-$ rich antigorite (Fig. 5b) also suggest a high temperature (400-600 ${ }^{\circ} \mathrm{C}$ ) for the serpentinization, accommodated by compositional adjustment of olivine at higher rates of $\mathrm{Mg}-$ Fe diffusion (Evans, 2010; Evans et al., 2012). The subsequent $\mathrm{Fe}$ rich alteration of the $\mathrm{Cr}$-spinel and presence of $\mathrm{Fe}$-oxides and $\mathrm{Fe}-\mathrm{Ti}$ oxides suggests their mobilization in later metasomatic process, post to the serpentinization of the peridotites (Gamal El Dien et al., 2019; Nozaka, 2018).

The CPO pattern in the foliated antigorite (Fig. 7a) 


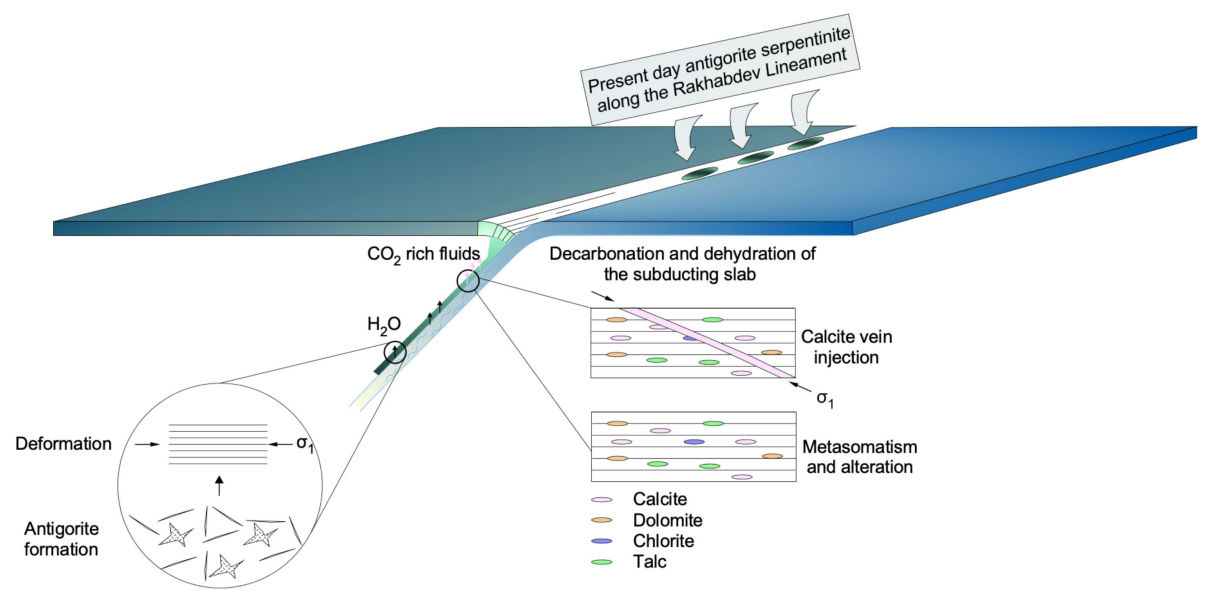

Figure 9. Schematic diagram showing the stages of formation and ensuing deformation of the Rakhabdev serpentinites. The generation of random blades and interpenetrative antigorite as a result of hydration of mantle peridotites at high pressures, followed by deformation into foliated antigorite. The foliated antigorite underwent metasomatism and alteration resulting in formation of talc-tremolite and calcite, with dolomite and chlorite. Calcite vein injection postdate all other deformation and fills into the fractures during exhumation. represents the antigorite $\mathrm{CPO}$ pattern common with other antigorite samples reported from forearc mantle body (Nishii et al., 2011), with the $c$-axis perpendicular to the foliation and the $\boldsymbol{b}$-axis parallel to the stretching lineation. The $\sigma_{1}$ direction being parallel to foliation suggests horizontal orientation. The antigorite deformation behavior is controlled by the structural relationship between olivine in peridotite and antigorite, which again depends on the fluid flow pathways controlled by the geometry of the initial olivine fabric and the topotactic relationship between olivine and antigorite (Watanabe et al., 2011). Few pseudomorphs of antigorite are present (Fig. 5d). However, in the absence of parent mantle mineral grains such inferences cannot be drawn from these samples.

\section{Metasomatism and deformation at shallow crust}

The presence of calcite + talc + tremolite + chlorite + dolomite assemblage suggests secondary metasomatism of already-hydrated mantle peridotite at a shallower depth, with high $\mathrm{CO}_{2}$ partial pressure (Schandl and Naldrett, 1992; Soda and Takagi, 2010) leading to alterations of the relict forsterite grains associated with bladed antigorite. This secondary metasomatism led to the generation of calcite, talc-tremolite, and chlorite within the weak planes of antigorite. Deformation at a shallower level has resulted in the development of weak crenulation of foliated antigorite and alteration to talc-tremolite and chlorite in the microlithon domains. The variation in $\mathrm{Al}$ content (Table S1) of the massive and deformed antigorite in contact with late calcite/dolomite, implies a possible variation in mineralogy of the parent mineral. The calcite veins cutting the foliated antigorite and the talctremolite grains suggest their injection at a later stage of $\mathrm{CO}_{2}$ metasomatism postdating the antigorite-forming hydration event, during shallow crustal deformation. The CPO of calcite within the veins, suggests the develop- ment of $\mathrm{c}<\mathrm{a}>$ as dominant slip system (Fig. 7b), as a result of plastic deformation of calcite at $>250{ }^{\circ} \mathrm{C}$ (Burkhard, 1993). The orientation of maximum principal stress $(\sigma 1)$ axes at shallow crustal deformation is represented by the orientation of the $c$-axes of calcite crystals (Fig. 7b) (Kamb, 1959; Romeo et al., 2007).

\section{TECTONIC SCENARIO}

The antigorite serpentinites of the Rakhabdev lineament record the deformation in three stages (Fig. 9). The first being the deformation of antigorite in upper mantle conditions (Fig. 5c). The deformed antigorite underwent exhumation and further shallow crustal $\mathrm{CO}_{2}$ rich metasomatism resulting in the alteration of serpentinites into talctremolite-calcite-dolomite-chlorite assemblage. This was followed by intrusion of calcite veins (at a later stage of $\mathrm{CO}_{2}$ metasomatism), cutting across all other features (Fig. 5f). No relict upper mantle minerals except $\mathrm{Cr}-$ spinels (with $\mathrm{Fe}$-enrichment towards the rim) are observed in the analyzed samples since the entire rock is metasomatized. The exhumation of the hydrated upper mantle material and its subsequent shallow crustal metasomatism is possible during ongoing subduction, along the exhuming channels at the interface of the subducting slab and mantle wedge. Also, since metamorphosed deep-sea sediments are reported from the western margin of the presently studied antigorite exposures (Roy and Jakhar, 2002), it further supports the idea of Rakhabdev being a tectonic lineament preserving hydrated mantle rocks. Further studies are required on the regional deformation pattern of the Rakhabdev lineament to elucidate the related tectonic scenario. The timing of this tectonism is also important to determine the integrated tectonics of this paleo-subduction zone and the eventual closure of the paleo-ocean in the overall evolution of ADMB. 


\section{ACKNOWLEDGMENTS}

This study was supported by the Doctoral fellowship from MEXT (Grant Number 195278 to D.P.S) and Research abroad grant by Graduate School of Science, Hiroshima University to D.P.S. We would also like to thank H. Ishishako of Monozukuri Plaza of Hiroshima University for his assistance in the preparation of thinsections and Y. Shibata of N-BARD Hiroshima University for technical assistance in using the electron microprobe. We are also indebted to Dr. Soda and another anonymous reviewer for their critical comments that helped in the improvement of the manuscript.

\section{SUPPLEMENTARY MATERIALS}

Supplementary Figure S1 and Table S1 are available online from https://doi.org/10.2465/jmps.191016.

\section{REFERENCES}

Abu-Hamatteh, Z.S.H., Raza, M. and Ahmad, T. (1994) Geochemistry of early Proterozoic mafic and ultramafic rocks of Jharol Group, Rajasthan, Northwestern India. Journal of Geological Society of India, 44, 141-156.

Andreani, M., Mével, C., Boullier, A.-M. and Escartín, J. (2007) Dynamic control on serpentine crystallization in veins: Constraints on hydration processes in oceanic peridotites. Geochemistry, Geophysics, Geosystems, 8. doi:10.1029/ 2006 GC001373.

Arai, S. and Ishimaru, S. (2008) Insights into Petrological Characteristics of the Lithosphere of Mantle Wedge beneath Arcs through Peridotite Xenoliths: a Review. Journal of Petrology, 49, 665-695.

Austin, N., Evans, B., Herwegh, M. and Ebert, A. (2008) Strain localization in the Morcles nappe (Helvetic Alps, Switzerland). Swiss Journal of Geosciences, 101, 341-360.

Auzende, A.-L., Daniel, I., Reynard, B., Lemaire, C. and Guyot, F. (2004) High-pressure behaviour of serpentine minerals: a Raman spectroscopic study. Physics and Chemistry of Minerals, 31, 269-277.

Auzende, A.-L., Escartin, J., Walte, N.P., Guillot, S., et al. (2015) Deformation mechanisms of antigorite serpentinite at subduction zone conditions determined from experimentally and naturally deformed rocks. Earth and Planetary Science Letters, 411, 229-240.

Bhu, H., Sarkar, A., Purohit, R. and Banerjee, A. (2006) Characterization of fluid involved in ultramafic rocks along the Rakhabdev Lineament from southern Rajasthan, northwest India. Current Science, 91, 1251-1256.

Boudier, F., Baronnet, A. and Mainprice, D. (2009) Serpentine mineral replacements of natural olivine and their seismic implications: Oceanic lizardite versus subduction-related antigorite. Journal of Petrology, 51, 495-512.

Bromiley, G.D. and Pawley, A.R. (2003) The stability of antigorite in the systems $\mathrm{MgO}-\mathrm{SiO}_{2}-\mathrm{H}_{2} \mathrm{O}(\mathrm{MSH})$ and $\mathrm{MgO}-\mathrm{Al}_{2} \mathrm{O}_{3^{-}}$ $\mathrm{SiO}_{2}-\mathrm{H}_{2} \mathrm{O}$ (MASH): The effects of $\mathrm{Al}^{3+}$ substitution on high-pressure stability. American Mineralogist, 88, 99-108.
Burkhard, M. (1993) Calcite twins, their geometry, appearance and significance as stress-strain markers and indicators of tectonic regime: a review. Journal of Structural Geology, 15, 351-368.

Campione, M. and Capitani, G.C. (2013) Subduction-zone earthquake complexity related to frictional anisotropy in antigorite. Nature Geoscience, 6, 847-851.

de Bresser, J.H.P. and Spiers, C.J. (1993) Slip systems in calcite single crystals deformed at $300-800{ }^{\circ} \mathrm{C}$. Journal of Geophysical Research: Solid Earth, 98, 6397-6409.

Deb, M., Thorpe, R.I., Cumming, G.L. and Wagner, P.A. (1989) Age, source and stratigraphic implications of $\mathrm{Pb}$ isotope data for conformable, sediment-hosted, base metal deposits in the Proterozoic Aravalli-Delhi orogenic belt, northwestern India. Precambrian Research, 43, 1-22.

Deb, M. and Thrope, R.I. (2001) Geochronological constraints in the Precambrian Geol- ogy of Northwestern India and their Metallogenic Implication. In International Workshop on Sediment-Hosted Lead-Zinc Sulfide Deposit in the Northwestern Indian Shield (Deb, M. snd Goodfellow, W.D. (Eds.). DelhiUdaipur, India. 137-152.

Debret, B., Albers, E., Walter, B., Price, R., et al. (2019) Shallow forearc mantle dynamics and geochemistry: New insights from IODP Expedition 366. Lithos, 326-327, 230-245.

Enami, M. (2006) Mineralogical methods for identification of asbestos and their limitations. Japanese Magazine of Mineralogical and Petrological Sciences, 35, 11-21 (Japanese with English abstract).

Evans, B.W. (2010) Lizardite versus antigorite serpentinite: Magnetite, hydrogen, and life(?). Geology, 38, 879-882.

Evans, B.W., Dyar, M.D. and Kuehner, S.M. (2012) Implications of ferrous and ferric iron in antigorite. American Mineralogist, 97, 184-196.

Evans, B.W., Hattori, K. and Baronnet, A. (2013) Serpentinite: What, Why, Where? Elements, 9, 99-106.

Gamal El Dien, H., Arai, S., Doucet, L., Li, Z., et al. (2019) Crspinel records metasomatism not petrogenesis of mantle rocks. Nature Communications, 5103.

Gathania, C.R., Chattopadhyay, A.K., Sharma, B., Ameta, S.S. and Ghosal, A.K. (1995) Occurrence of ultramafics of komatiitic affinity in the Rikhabdev-Dungarpur belt, Udaipur and Dungarpur districts, Rajasthan. Journal of Geological Society of India, 46, 585-594.

Griffith, W.P. and Wickins, T.D. (1967) Studies on transition-metal peroxy-complexes. Part V. Peroxyoxalates. Journal of the Chemical Society A: Inorganic, Physical, Theoretical, 590592.

Gupta, P., Fareeduddin, Reddy, M.S. and Mukhopadhayay, K. (1995) Stratigraphy and structure of Delhi Supergroup rocks in the central part of the Aravalli range. Recordings in Geological Survey of India, 120, 12-26.

Gupta, S.N., Arora, Y.K., Mathur, R.K., Iqballuddin, Prasad, B., et al. (1997) The Precambrian Geology of the Aravalli region, Southern Rajasthan and Northeast Gujrat. pp. 266, Memoirs of the Geological Surervey of India, 123.

Heron, A.M. (1953) The geology of central Rajputana. Memoirs of the Geological Soceity of Inia, 79.

Hirauchi, K., Michibayashi, K., Ueda, H. and Katayama, I. (2010) Spatial variations in antigorite fabric across a serpentinite subduction channel: Insights from the Ohmachi Seamount, IzuBonin frontal arc. Earth and Planetary Science Letters, 299, 196-206.

Kamb, W.B. (1959) Theory of Preferred Crystal Orientation De- 
veloped by Crystallization under Stress. The Journal of Geology, 67, 153-170.

Kawano, S., Katayama, I. and Okazaki, K. (2011) Permeability anisotropy of serpentinite and fluid pathways in a subduction zone. Geology, 39, 939-942.

Loh, E. (1973) Optical vibrations in sheet silicates. Journal of Physics C: Solid State Physics, 6, 1091-1104.

Mizukami, T., Yokoyama, H., Hiramatsu, Y., Arai, S., et al. (2014) Two types of antigorite serpentinite controlling heterogeneous slow-slip behaviours of slab-mantle interface. Earth and Planetary Science Letters, 401, 148-158.

Murata, K., Maekawa, H., Yokose, H., Yamamoto, K., et al. (2009) Significance of serpentinization of wedge mantle peridotites beneath Mariana forearc, western Pacific. Geosphere, 5, 90104.

Nakatani, T. and Nakamura, M. (2016) Experimental constraints on the serpentinization rate of fore-arc peridotites: Implications for the upwelling condition of the slab-derived fluid. Geochemistry, Geophysics, Geosystems, 17, 3393-3419.

Nishii, A., Wallis, S.R., Mizukami, T. and Michibayashi, K. (2011) Subduction related antigorite CPO patterns from forearc mantle in the Sanbagawa belt, southwest Japan. Journal of Structural Geology, 33, 1436-1445.

Nozaka, T. (2018) Compositional variation of olivine related to high-temperature serpentinization of peridotites: Evidence from the Oeyama ophiolite. Journal of Mineralogical and Petrological Sciences, 113, 219-231.

Pawley, A.R. (1998) The reaction talc + forsterite $=$ enstatite $+\mathrm{H}_{2} \mathrm{O}$; new experimental results and petrological implications. American Mineralogist, 83, 51-57.

Petriglieri, J.R., Salvioli-Mariani, E., Mantovani, L., Tribaudino, M., et al. (2015) Micro-Raman mapping of the polymorphs of serpentine. Journal of Raman Spectroscopy, 46, 953-958.

Plissart, G., González-Jiménez, J.M., Garrido, L.N.F., Colás, V., et al. (2019) Tectono-metamorphic evolution of subduction channel serpentinites from South-Central Chile. Lithos, 336337, 221-241.

Prasad, B.R., Tewari, H.C., Rao, V.V., Dixit, M.M., et al. (1998) Structure and tectonics of the Proterozoic Aravalli-Delhi Fold Belt in northwestern India from deep seismic reflection studies. Tectonophysics, 288, 31-41.

Purohit, R., Bhu, H., Sarkar, A. and Ram, J. (2015) Evolution of the ultramafic rocks of the Rakhabdev and Jharol belts in southeastern Rajasthan, India: New evidences from imagery mapping, petro-mineralogical and $\mathrm{O}-\mathrm{H}$ stable isotope studies. Journal of the Geological Society of India, 85, 331-338.

Rinaudo, C.A., Gastaldi, D.A. and Belluso, E. (2003) Characterization of Chrysotile, Antigorite and Lizardite by FT-Raman Spectroscopy. The Canadian Mineralogist, 41, 883-890.

Romeo, I., Capote, R. and Lunar, R. (2007) Crystallographic preferred orientations and microstructure of a Variscan marble mylonite in the Ossa-Morena Zone (SW Iberia). Journal of Structural Geology, 29, 1353-1368.

Roy, A.B. and Jakhar, S.R. (2002) Geology of Rajasthan (Northwest India) Precambrian to recent. Scientific Publishers.

Sarkar, G., Barman, T.R. and Corfu, F. (1989) Timing of Continental Arc-Type Magmatism in Northwest India: Evidence from U-Pb Zircon Geochronology. Journal of Geology, 97, 607612.
Schandl, E.S. and Naldrett, A.J. (1992) $\mathrm{CO}_{2}$ metasomatism of serpentinites, south of Timmins, Ontario. Canadian Mineralogist, 30, 93-108.

Sharma, R. (2010) Cratons and Fold Belts of India, $1^{\text {st }}$ ed. Lecture Notes in Earth Sciences. Springer, Berlin Heidelberg.

Shekhawat, M.S., Ranawat, M.S. and Ranawat, P.S. (2010) Mineralogical and chemical characteristics of talc and tremolite asbestos hosting Proterozoic ultramafic rocks of Jharol area, Udaipur, Rajasthan. International Journal of Earth Sciences and Engineering, 3, 459-474.

Singh, Y.K., De Waele, B., Karmakar, S., Sarkar, S. and Biswal, T.K. (2010) Tectonic setting of the Balaram-Kui-SurpaglaKengora granulites of the South Delhi Terrane of the Aravalli Mobile Belt, NW India and its implication on correlation with the East African Orogen in the Gondwana assembly. Precambrian Research, 183, 669-688.

Soda, Y. and Takagi, H. (2010) Sequential deformation from serpentinite mylonite to metasomatic rocks along the Sashu Fault, SW Japan. Journal of Structural Geology, 32, 792-802.

Sugden, T.J., Deb, M. and Windley, B.F. (1990) The Tectonic Setting of Mineralisation in the Proterozoic Aravalli Delhi Orogenic Belt, Nw India. Developments in Precambrian Geology, 367-390.

Tiwari, S.K. and Biswal, T.K. (2019) Palaeostress and magma pressure measurement of granite veins in the Neoproterozoic Ambaji granulite, South Delhi terrane, Aravalli-Delhi mobile belt, NW India: Implication towards the extension-driven exhumation of the middle-lower crustal rocks. Journal of Earth System Science, 128.

Uehara, S. (1998) TEM and XRD study of antigorite superstructures. Canadian Mineralogist, 36, 1595-1605.

Uno, M. and Kirby, S. (2019) Evidence for multiple stages of serpentinization from the mantle through the crust in the Redwood City Serpentinite mélange along the San Andreas Fault in California. Lithos, 336-337, 276-292.

Vauchez, A., Clerc, C., Bestani, L., Lagabrielle, Y., et al. (2015) Preorogenic exhumation of the North Pyrenean Agly massif (Eastern Pyrenees-France). Tectonics, 32, 95-106.

Verma, P.K. and Greiling, R.O. (1995) Tectonic evolution of the Aravalli orogen (NW India): an inverted Proterozoic rift ba$\sin$ ? Geologische Rundschau, 84, 683-696.

Watanabe, T., Shirasugi, Y., Yano, H. and Michibayashi, K. (2011) Seismic velocity in antigorite-bearing serpentinite mylonites. In Deformation Mechanisms, Rheology and Tectonics: Microstructures, Mechanics and Anisotropy (Prior, D.J., Rutter, E.H. and Tatham, D.J. Eds.). Geological Society, London, Special Publications, 360, 97-112.

Wicks, F.J. and Whittaker, E.J.W. (1975) A reappraisal of the structures of the serpentine minerals. Canadian Mineralogist, 13, 227-243.

Wunder, B., Wirth, R. and Gottschalk, M. (2001) Antigorite: Pressure and temperature dependence of polysomatism and water content. European Journal of Mineralogy, 13, 485-495.

Manuscript received October 16, 2019

Manuscript accepted February 28, 2020

Published online March 31, 2020

Manuscript handled by Toru Inoue 